\title{
Effects of fishing disturbance on benthic communities and secondary production within an intensively fished area
}

\author{
Henning Reiss ${ }^{1,2, *}$, Simon P. R. Greenstreet ${ }^{3}$, Katrin Sieben ${ }^{1,2}$, Siegfried Ehrich ${ }^{4}$, \\ Gerjan J. Piet ${ }^{5}$, Floor Quirijns ${ }^{5}$, Leonie Robinson ${ }^{6}$, Wim J. Wolff ${ }^{2}$, Ingrid Kröncke ${ }^{1}$ \\ ${ }^{1}$ Department for Marine Research, Senckenberg Institute, Südstrand 40, 26382 Wilhelmshaven, Germany \\ ${ }^{2}$ Department of Marine Benthic Ecology and Evolution, University of Groningen, Postbus 14, 9750 AA Haren, The Netherlands \\ ${ }^{3}$ Marine Laboratory, Fisheries Research Services, PO Box 101, Aberdeen AB11 9DB, UK \\ ${ }^{4}$ Institute of Sea Fisheries, Federal Research Institute for Rural Areas, Forestry and Fisheries, Palmaille 9, \\ 22767 Hamburg, Germany \\ ${ }^{5}$ Wageningen IMARES, Postbus 68, 1970 IJmuiden, The Netherlands \\ ${ }^{6}$ Ecosystem Dynamics Group, School of Biological Sciences, University of Liverpool, PO Box 147, Liverpool L69 3BX, UK
}

\begin{abstract}
Demersal fishing alters seabed habitats and affects the structure and functioning of benthic invertebrate communities. At a critical level of disturbance, such communities may approach an equilibrium disturbed state in which a further increase in disturbance has little additional impact. Such arguments have been used to suggest that an ecosystem approach to fisheries management (EAFM) should protect lightly fished areas and deflect fishing activity into areas that are already intensively fished. In this study, the effects of variation in fishing disturbance on the secondary production, species diversity, abundance, biomass, and community structure of benthic infauna were examined in a region of the German Bight (North Sea) that has been intensively trawled for decades. Variation in fishing disturbance across the study area was determined using automated position registration and vessel monitoring through satellite. Even in such a heavily fished area, linear regression analyses revealed that biomass, species richness, and production decreased significantly with increasing fishing intensity. Although redundancy analyses (RDA) showed that sediment characteristics were influential in determining the structure of the infauna community, partial RDA revealed that fishing continued to have an impact on community structure in terms of biomass. These results suggest that, in implementing an EAFM, managers will need to consider the possibility that, even in areas with high chronic fishing disturbance, further increases in fishing activity may still cause additional damage to benthic invertebrate communities.
\end{abstract}

KEY WORDS: Ecosystem functioning $\cdot$ Ecosystem management $\cdot$ Fishing impact $\cdot$ Benthic production · Species diversity $\cdot$ North Sea

Resale or republication not permitted without written consent of the publisher

\section{INTRODUCTION}

Fishing activity in the North Sea has increased markedly over the course of the 20th century (Daan et al. 1990, Greenstreet et al. 1999), and consideration of the effects of this on various components of the marine ecosystem has generated considerable interest. Addressing the issues raised has brought about pro- found changes in the way that marine natural resources are being managed: away from the traditional single-species approach applied to the targeted commercial species, towards a more holistic ecosystem approach to fisheries management (EAFM) (Gislason et al. 2000, Hall \& Mainprize 2004, Cury \& Christensen 2005, Garcia \& Cochrane 2005, Frid et al. 2006). Full implementation of an EAFM requires understanding of 
the impacts of fishing on all major ecosystem components, and of the consequences of these on ecosystem functioning.

Two approaches have generally been adopted to examine the impact of fishing on the benthic invertebrate component of marine ecosystems. Firstly, experimental fishing studies, usually undertaken in lightly or unfished areas (Kaiser et al. 2006), have focused on the immediate direct effects of the passage of fishing gears over 'previously undisturbed' benthic communities. These experimental studies, which have revealed effects at both species (e.g. Tuck et al. 1998, Sanchez et al. 2000, Kenchington et al. 2006) and community levels (e.g. Thrush et al. 1995, Kaiser \& Spencer 1996, Kaiser et al. 1998), have recently been comprehensively reviewed in 2 meta-analyses that have derived broad overviews of the immediate direct impact of fishing disturbance on benthic invertebrate communities (Collie et al. 2000, Kaiser et al. 2006).

An alternative approach involves the comparison of benthic invertebrate communities across gradients of fishing intensity. Generally, such studies have focused on changes in the benthic community brought about by fishing disturbance that is integrated over prolonged periods (Frid et al. 1999), and in recent years have tended to concentrate on the larger epifaunal components of the benthic ecosystem, rather than on infaunal communities (Blyth et al. 2004, Tillin et al. 2006). Within epifaunal communities, reductions in biomass, secondary production and species diversity have frequently been associated with increased fishing disturbance (Hiddink et al. 2006, Tillin et al. 2006), but the relationships are not so clear-cut among infaunal communities. In some cases, significant relationships between infaunal production and fishing intensity have simply not been detected (Jennings et al. 2002). In others, the interpretation of comparisons of infaunal communities across fishing effort gradients has been hampered by strong, covarying gradients in environmental conditions, which also influence the distributions of individual infaunal species and contribute to the structuring of infaunal communities (e.g. Queirós et al. 2006). An alternative hypothesis that intensive trawling may even enhance secondary production among the smaller benthic organisms (e.g. Rijnsdorp \& Vingerhoed 2001, van Keeken et al. 2007, Hiddink et al. 2008) cannot be discounted at this stage (but see Jennings et al. 2002).

The southern North Sea has been heavily fished throughout the 20th century, and this persistent disturbance to the benthic community from fishing may have altered the benthic fauna to form more resilient, disturbance-adapted communities (e.g. Kaiser et al. $2000 a, b)$. At a specific high level of disturbance, benthic communities may approach an equilibrium dis- turbed state in which a further increase in disturbance has little additional impact. Indeed, recent theoretical size-based modelling has suggested this to be the case in terms of effects on infaunal production and biomass in areas of the North Sea that are already heavily fished (Duplisea et al. 2002, Hiddink et al. 2006). Since future ecosystem-based fisheries management strategies will be mainly based on the modulation of fishing activities within these existing fishing areas, it is important that we test these theoretical predictions. If the predictions are right, reducing fishing effort in areas that have been heavily fished for many years would be of little benefit to the benthic component of the ecosystem.

In this study, we investigated the variation in infaunal community characteristics (total abundance, biomass, species diversity and community structure) and a key ecosystem process (production) across a quantified fishing effort gradient within an area of homogeneous soft-bottom habitat in the southern North Sea that has been heavily trawled for decades. The overall objective was to investigate whether the effects of fishing on benthic infaunal community structure and function were detectable in areas with long histories of fishing.

\section{MATERIALS AND METHODS}

Study area. The study area, which is part of the 'German small-scale bottom trawl survey' (GSBTS) (Ehrich et al. 2007), is located in the German Bight 20 nautical miles (n miles) northwest of the island of Helgoland (Fig. 1). The area was chosen for several reasons. Firstly, beam trawls (heavy gears that are towed quickly and penetrate deeply into the sediment) are widely used here, beam trawling being generally considered to be one of the most damaging of anthropogenic activities to North Sea benthic communities (e.g. Piet et al. 2000). The study area is situated in one of the most heavily beam-trawled ICES statistical rectangles in the North Sea (Jennings et al. 1999, Piet et al. 2007), and can be considered to be occupied by a benthic community that has been subjected to chronic long-term heavy fishing disturbance. Secondly, the study area is situated just outside the plaice box, which was established in 1989 to reduce bycatch mortality on juvenile plaice. Introduction of the plaice box resulted in a major reallocation of effort to adjacent areas (Piet \& Rijnsdorp 1998, Pastoors et al. 2000), which is likely to have subjected the study area to a sudden sharp increase in fishing pressure, in addition to its already being heavily fished. Thirdly, despite being located within a region of the North Sea which is considered to be heavily fished at the spatial scale of the ICES statistical rectangle, fishing intensity within the study area 


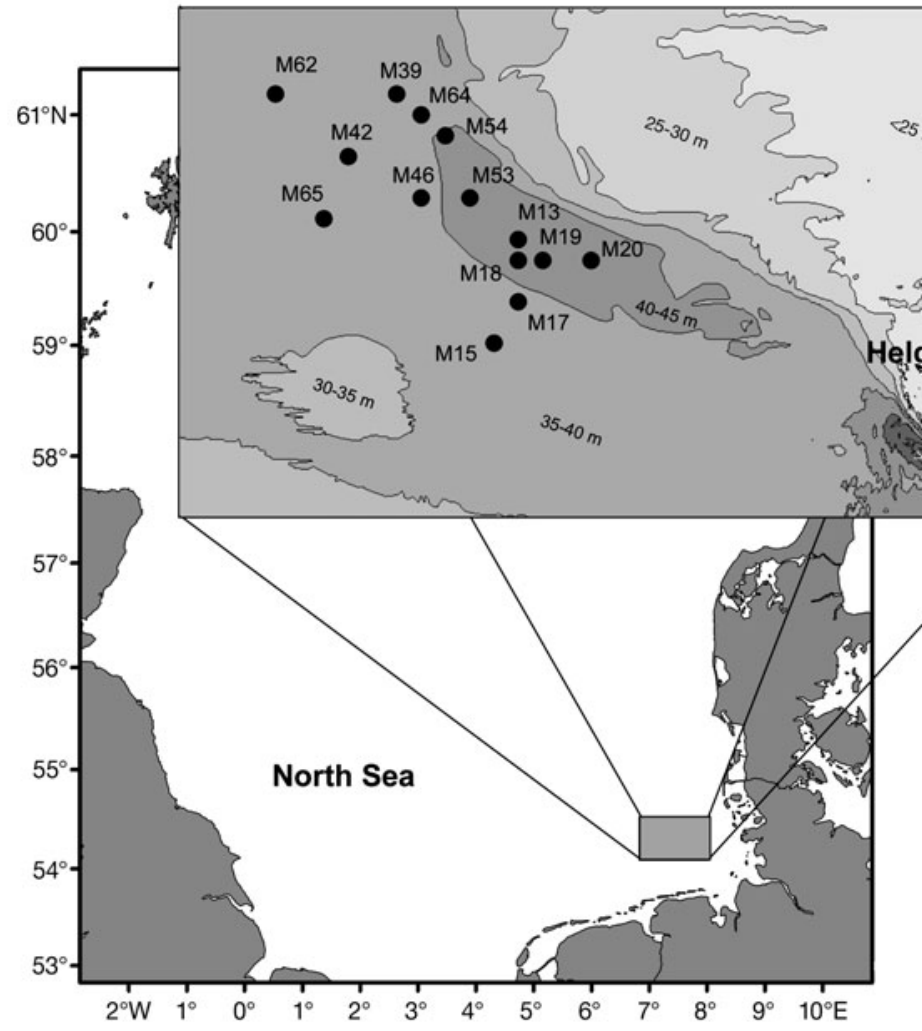

Fig. 1. Study area and sampled stations in the North Sea

still varies markedly at a finer spatial resolution. Finally, the area is relatively homogeneous in terms of environmental characteristics. It is 35 to $45 \mathrm{~m}$ deep, with muddy sand sediments. Mean water temperatures range from $4^{\circ} \mathrm{C}$ in winter to $17^{\circ} \mathrm{C}$ in summer (Ehrich et al. 2007). Variation in the characteristics of the benthic community are therefore likely to be driven far more by changes in fishing regime than by variation in environmental conditions.

Fishing disturbance. Fishing by Dutch beam trawlers represented $\sim 75 \%$ of international trawl effort in the area (van Keeken et al. 2007). Variation in fishing disturbance from larger Dutch beam trawlers (>300 hp) across the study area (determined as the number of times each 1 ' latitude $\times 2$ ' longitude (approximately $1 \times 1 \mathrm{n}$ mile) spatial subunit within the study area was fished per year (fishing frequency) was assessed following the methods established by Piet et al. (2007). This was derived from automated position registration data between 1994 and 1999 and from vessel monitoring through satellite data between 2000 and 2004. These data were screened to exclude location records where the vessels concerned were not involved in trawling activity (see Piet et al. 2007). To determine whether the duration of fishing disturbance had any discernible effect on the benthic infaunal com- munity, fishing intensity data were aggregated over 3 different periods: 'long-term' (1994 to 2004, 11 yr prior to infaunal sampling), 'mid-term' (2000 to 2004, 5 yr prior to sampling) and 'short-term' (2003 to 2004, 2 yr prior to sampling). A mean effort value per year was calculated for each period.

Infaunal sampling. The benthic infaunal community was sampled with a $0.1 \mathrm{~m}^{2}$ van Veen grab at 14 stations in July and August 2004 (Fig. 1). Stations were positioned near the centre of each $1 \times 1 \mathrm{n}$ mile grid cell that was used for fishing effort estimations. Three replicates were taken at each station. To obtain infaunal community size structure data, the samples were sieved through a sieve tower consisting of 4,2 and $1 \mathrm{~mm}$ mesh size sieves. Material retained within each sieve was fixed separately in $4 \%$ buffered formalin. Species abundance and biomass in each sieve-size fraction were assessed. Biomass per species was determined as ash-free dry weight (AFDW), first by wet weighing and then applying conversion factors (Rumohr et al. 1987, Ricciardi \& Bourget 1998, Brey 2001). All tubicolous polychaetes were removed from their tubes prior to weighing. Due to the high abundance of the tentaculate Phoronis muelleri at some stations, subsamples of at least $15 \%$ of the total wet weight were processed.

Environmental variables. Sediment samples were extracted from each van Veen infaunal grab sample using a $2 \mathrm{~cm}$ diameter plastic tube inserted to a depth of $10 \mathrm{~cm}$. Fresh sediment samples were frozen at $-20^{\circ} \mathrm{C}$.

For the analysis of mud content, one sample was subsequently freeze-dried and sieved through a $500 \mu \mathrm{m}$ sieve to remove large shell particles. An aliquot of each sample was placed into a laser particle sizer (Analysette 22 Economy), and automatically homogenized using a stirrer and by ultrasonication. The percentage of different grain size fractions was measured, and the grain size fraction that was $<63 \mu \mathrm{m}$ was considered as the mud content (\%) of the sediment.

Sediment total organic carbon (TOC) and nitrogen (TON) were also determined on freeze-dried samples that had been finely powdered and homogenized. A 10 to $30 \mathrm{mg}$ subsample was combusted at $1010^{\circ} \mathrm{C}$ in a $\mathrm{C} / \mathrm{N}$ analyser (Heraeus) within silver sample cups following acidification of the samples with evaporated concentrated $\mathrm{HCl}$ in a desiccator to remove inorganic carbonates (Hedges \& Stern 1984).

Water temperature and salinity through the whole water column were measured at each station using a self-recording CTD profiler (SEABIRD SBE-19Plus). Over the course of the 4 wk cruise, thermal and (slight) salinity stratification of the water column occurred in the entire study area. Due to the time lag during sam- 
pling (sampling took place at the beginning and end of the cruise), the differences in temperature and salinity therefore reflected temporal and not spatial variation. Thus, surface temperature and salinity were used in all statistical analyses.

Data analyses. Total abundance and biomass are given as mean values sampled per $\mathrm{m}^{2}$ at each station. Diversity metrics (species number; Shannon-Wiener index, $H^{\prime}\left(\log _{\mathrm{e}}\right)$; and Pielou's evenness, $\left.J^{\prime}\right)$ were calculated on the aggregated data from all 3 replicate samples (e.g. Greenstreet \& Piet 2008) collected at each station using the PRIMER version 6 (Clarke \& Warwick 1994) software package. Annual somatic production $\left(P ; \mathrm{kJ} \mathrm{yr}^{-1} \mathrm{~m}^{-2}\right)$ was estimated using the empirical method proposed by Brey (2001):

$$
\begin{aligned}
\log P= & \log B+C-2.294 \log M-\frac{2409.856}{(T+273)}+ \\
& \frac{0.168}{D}+\frac{582.851 \log M}{(T+273)}
\end{aligned}
$$

where $P$ is the annual production $\left(\mathrm{kJ} \mathrm{yr}^{-1} \mathrm{~m}^{-2}\right), M$ is the mean individual body mass converted to an energetic equivalent using appropriate conversion factors (Brey 2001) (kJ), $B$ is the biomass of each species in the 'sample' which is also converted to energetic equivalent $(\mathrm{kJ}), T$ is water temperature $\left({ }^{\circ} \mathrm{C}\right), D$ is water depth $(\mathrm{m})$, and $C$ is a taxon-dependent constant (8.495 for annelid and crustacean taxa, 8.133 for echinoderms, and 8.321 for all other taxa). Total community production was calculated for each sample by summing up the production values per species.

Pearson's correlation was used to determine the relationships between fishing effort and environmental variables. The relationships between fishing effort and univariate parameters of the infaunal community, such as diversity measures, abundance, biomass and secondary production, were tested using linear regression.

Multivariate ordination methods were used to define infaunal community structure and examine the relationships between community structure and environmental variables as well as fishing pressure. Analyses were performed based on abundance and biomass data using CANOCO 4.5 (ter Braak \& Smilauer 1998). Gradient length (expressed in SD units), which is a measure of how unimodal the species responses are along an ordination axis, was determined using detrended correspondence analysis (DCA). Since all values were below $3 \mathrm{SD}$, subsequent analyses were based on linear species-response models (Jongman et al. 1995, ter Braak \& Smilauer 1998), allowing relationships between infaunal community structure and environmental variables to be further analyzed using redundancy analysis (RDA). RDA is a constrained linear ordination method where the ordination axes are linear combinations of the environ- mental variables. Environmental variables examined were mud content, total organic carbon content (TOC), total organic nitrogen content (TON), C/N ratio, surface water temperature, salinity, and depth as well as fishing effort for each of the 3 time periods mentioned above. Forward selection was performed to arrange the environmental variables according to the amount of variance in the species data they captured (ter Braak \& Verdonschot 1995). Statistical significance was tested using a Monte Carlo permutation test (999 unrestricted permutations).

Additionally, partial RDA and variance partitioning (Borcard et al. 1992) was used to estimate the importance of fishing pressure alone on the infaunal community structure. Here, residual variance in community structure was related to fishing pressure after accounting for the influence of all environmental variables which were treated as covariables, and vice versa. The covariables used in the partial RDA were all the environmental variables listed above.

\section{RESULTS}

For all the time periods considered, fishing intensity ( $\approx$ fishing effort) of the spatial units ranged from a frequency of 0 to 4.4 times trawled $\mathrm{yr}^{-1}$ (Table 1). Within the entire German Bight region, $73 \%$ of $1 \times 1 \mathrm{n}$ mile spatial subunits were fished with an intensity lying between these lowest and highest values observed at the sampled stations. Only $2 \%$ of the German Bight region was more intensively fished than the most heavily fished station.

The infaunal community in the study area belong to the Nucula nitidosa community (Kröncke \& Rachor 1992, Reiss \& Kröncke 2005). The most dominant species based on abundance and biomass as well as the mean community characteristics are listed in Table 2. The dominance structure of the infaunal community was rather similar in the entire study area, with the tentaculate Phoronis muelleri and the polychaete Owenia fusiformis being the most abundant species, and the bivalve Nucula nitidosa and the echinoderm Echinocardium cordatum dominating the biomass (Table 2). Higher abundances in the heavily trawled area compared to the lightly trawled area were mainly found for opportunistic species such as P. muelleri, O. fusiformis and the polychaete Lagis koreni, whereas especially N. nitidosa and the brittle star Amphiura filiformis were more abundant and showed higher biomass values in the lightly trawled area (Table 2).

Infaunal mean total biomass, secondary production and species number decreased significantly with increasing fishing effort (Fig. 2). In terms of biomass, the duration of the fishing effort period considered made 
Table 1. Environmental characteristics and fishing effort (frequency trawled $\mathrm{yr}^{-1}$ ) of the sampled stations. TOC: Total organic carbon, TON: total organic nitrogen

\begin{tabular}{|c|c|c|c|c|c|c|c|c|c|c|}
\hline Station & $\begin{array}{c}<63 \mu \mathrm{m} \\
(\%)\end{array}$ & $\begin{array}{c}\text { TOC } \\
(\%)\end{array}$ & $\begin{array}{l}\text { TON } \\
(\%)\end{array}$ & $\mathrm{C} / \mathrm{N}$ ratio & $\begin{array}{c}\text { Temperature } \\
\left({ }^{\circ} \mathrm{C}\right)\end{array}$ & Salinity & $\begin{array}{l}\text { Depth } \\
\text { (m) }\end{array}$ & $\begin{array}{c}\text { Long-term } \\
(1994-2004)\end{array}$ & $\begin{array}{l}\text { Fishing effort } \\
\text { Mid-term } \\
(2000-2004)\end{array}$ & $\begin{array}{l}\text { Short-term } \\
(2003-2004)\end{array}$ \\
\hline M13 & 14.0 & 0.222 & 0.025 & 8.9 & 18.3 & 31.9 & 43 & 2.05 & 2.67 & 1.35 \\
\hline M15 & 20.1 & 0.302 & 0.037 & 8.1 & 17.3 & 32.5 & 37 & 0.76 & 1.32 & 1.20 \\
\hline M17 & 18.1 & 0.277 & 0.033 & 8.3 & 18.6 & 32.2 & 41 & 0.88 & 1.47 & 1.89 \\
\hline M18 & 17.7 & 0.269 & 0.033 & 8.1 & 18.9 & 32.0 & 43 & 0.28 & 0.33 & 0.53 \\
\hline M19 & 13.7 & 0.259 & 0.030 & 8.9 & 18.6 & 32.3 & 41 & 1.43 & 2.46 & 1.69 \\
\hline M20 & 11.5 & 0.200 & 0.022 & 9.2 & 18.9 & 31.4 & 43 & 1.77 & 2.33 & 1.80 \\
\hline M39 & 11.5 & 0.238 & 0.031 & 7.8 & 17.8 & 33.6 & 38 & 0.82 & 1.14 & 0.90 \\
\hline M42 & 16.8 & 0.251 & 0.031 & 8.1 & 18.1 & 33.5 & 39 & 0.76 & 0.71 & 0.89 \\
\hline M46 & 17.4 & 0.250 & 0.032 & 7.9 & 17.8 & 33.5 & 41 & 0.51 & 0.53 & 0.69 \\
\hline M53 & 12.5 & 0.224 & 0.027 & 8.3 & 17.6 & 33.5 & 43 & 1.08 & 1.55 & 1.06 \\
\hline M54 & 7.3 & 0.159 & 0.020 & 8.2 & 17.7 & 33.6 & 41 & 2.35 & 4.40 & 0.79 \\
\hline M62 & 15.9 & 0.257 & 0.033 & 7.9 & 18.2 & 33.9 & 38 & 0.36 & 0.42 & 0.16 \\
\hline M64 & 10.8 & 0.223 & 0.027 & 8.4 & 17.8 & 33.6 & 39 & 0.80 & 0.47 & 0.32 \\
\hline M65 & 23.1 & 0.314 & 0.038 & 8.2 & 18.4 & 33.7 & 39 & 0.37 & 0.58 & 0.00 \\
\hline
\end{tabular}

Table 2. Dominant species (based on abundance and biomass) of the infaunal community, diversity measures and secondary production in the study area (total mean and SD) for stations with high (M13, M20, M54) and low fishing effort (M18, M62, M65)

\begin{tabular}{|c|c|c|c|c|}
\hline & \multicolumn{2}{|c|}{ High effort } & \multicolumn{2}{|c|}{ Low effort } \\
\hline & Mean & $\mathrm{SD}$ & Mean & $\mathrm{SD}$ \\
\hline \multicolumn{5}{|l|}{ Abundance (ind. $\mathbf{m}^{-2}$ ) } \\
\hline Total & 28401 & 9875 & 17247 & 1328 \\
\hline \multicolumn{5}{|l|}{ Dominant species: } \\
\hline Phoronis muelleri & 20028 & 7627 & 11293 & 688 \\
\hline Owenia fusiformis & 3844 & 3022 & 1896 & 669 \\
\hline Lanice conchilega & 582 & 143 & 406 & 179 \\
\hline Amphiura filiformis & 274 & 126 & 728 & 174 \\
\hline Lagis koreni & 869 & 578 & 370 & 448 \\
\hline Abra nitida & 438 & 320 & 300 & 286 \\
\hline Nucula nitidosa & 153 & 106 & 344 & 83 \\
\hline Abra alba & 241 & 135 & 128 & 68 \\
\hline Spiophanes bombyx & 199 & 55 & 172 & 14 \\
\hline Echinocardium juvenile & 149 & 168 & 43 & 36 \\
\hline Phaxas pellucidus & 174 & 35 & 95 & 29 \\
\hline Magelona johnstoni & 121 & 139 & 41 & 49 \\
\hline Corbula gibba & 114 & 120 & 17 & 24 \\
\hline \multicolumn{5}{|l|}{ Biomass (g AFDW m ${ }^{-2}$ ) } \\
\hline Total & 12.21 & 2.95 & 18.17 & 2.08 \\
\hline \multicolumn{5}{|l|}{ Dominant species: } \\
\hline Nucula nitidosa & 3.28 & 2.50 & 4.78 & 0.74 \\
\hline Echinocardium cordatum & 4.17 & 0.67 & 5.41 & 0.96 \\
\hline Nephtys hombergii & 0.48 & 0.30 & 1.23 & 0.73 \\
\hline Phoronis muelleri & 0.89 & 0.44 & 0.76 & 0.09 \\
\hline Amphiura filiformis & 0.25 & 0.12 & 1.62 & 0.74 \\
\hline Lagis koreni & 0.76 & 0.43 & 0.30 & 0.29 \\
\hline Owenia fusiformis & 0.16 & 0.07 & 0.86 & 0.55 \\
\hline Nephtys assimilis & 0.22 & 0.17 & 0.31 & 0.12 \\
\hline Chamelea gallina & 0.01 & 0.00 & 0.37 & 0.36 \\
\hline Amphiura brachiata & 0.12 & 0.05 & 0.01 & 0.02 \\
\hline Production $\left(\mathrm{kJ} \mathrm{m}^{-2} \mathrm{yr}^{-1}\right)$ & 698 & 65 & 850 & 100 \\
\hline Shannon-Wiener $H^{\prime}\left(\log _{\mathrm{e}}\right)$ & 1.32 & 0.24 & 1.62 & 0.06 \\
\hline Evenness $J$ & 0.31 & 0.06 & 0.37 & 0.02 \\
\hline Species number $\left(0.3 \mathrm{~m}^{-2}\right)$ & 73 & 2 & 77 & 5 \\
\hline
\end{tabular}

no difference to the result, but the effect of fishing intensity on secondary production and species number was apparent only for the short-term fishing effort period (Fig. 2). Variations in fishing effort had no significant effect on mean total abundance, or on either of the diversity measures (the Shannon-Wiener and evenness index) that took species relative abundance into account.

Despite the relatively homogeneous environmental characteristics for which the study area was selected (Table 1), some covariance between fishing intensity and some environmental variables was apparent (Table 3). This raises the possibility that the changes in the infaunal community that are related to fishing intensity in Fig. 2 might instead have been caused by differences in sediment characteristics between the stations. This alternative explanation seems unlikely, however, considering the fact that no significant relationships were observed between infaunal biomass, production and species richness and any of the environmental variables examined (Fig. 3). On the other hand, infaunal abundance was significantly negatively related to sediment mud and TOC content (Fig. 3).

Separate analysis of the different size fractions revealed that fishing disturbance induced reduction in infaunal secondary production, mainly for the largersized animals in the community, i.e. those retained in the $4 \mathrm{~mm}$ sieve (Fig. 4). Among the animals retained in the $1 \mathrm{~mm}$ sieve, there was an apparent positive effect of fishing intensity on production. Although not statistically significant when all stations were considered, this relationship attained significance when the statistical outlier station, M18, was excluded from the analysis (long-term $\mathrm{r}=0.742, \mathrm{p}=0.004$; mid-term $\mathrm{r}=0.655$, $p=0.015$; Fig. 4) 

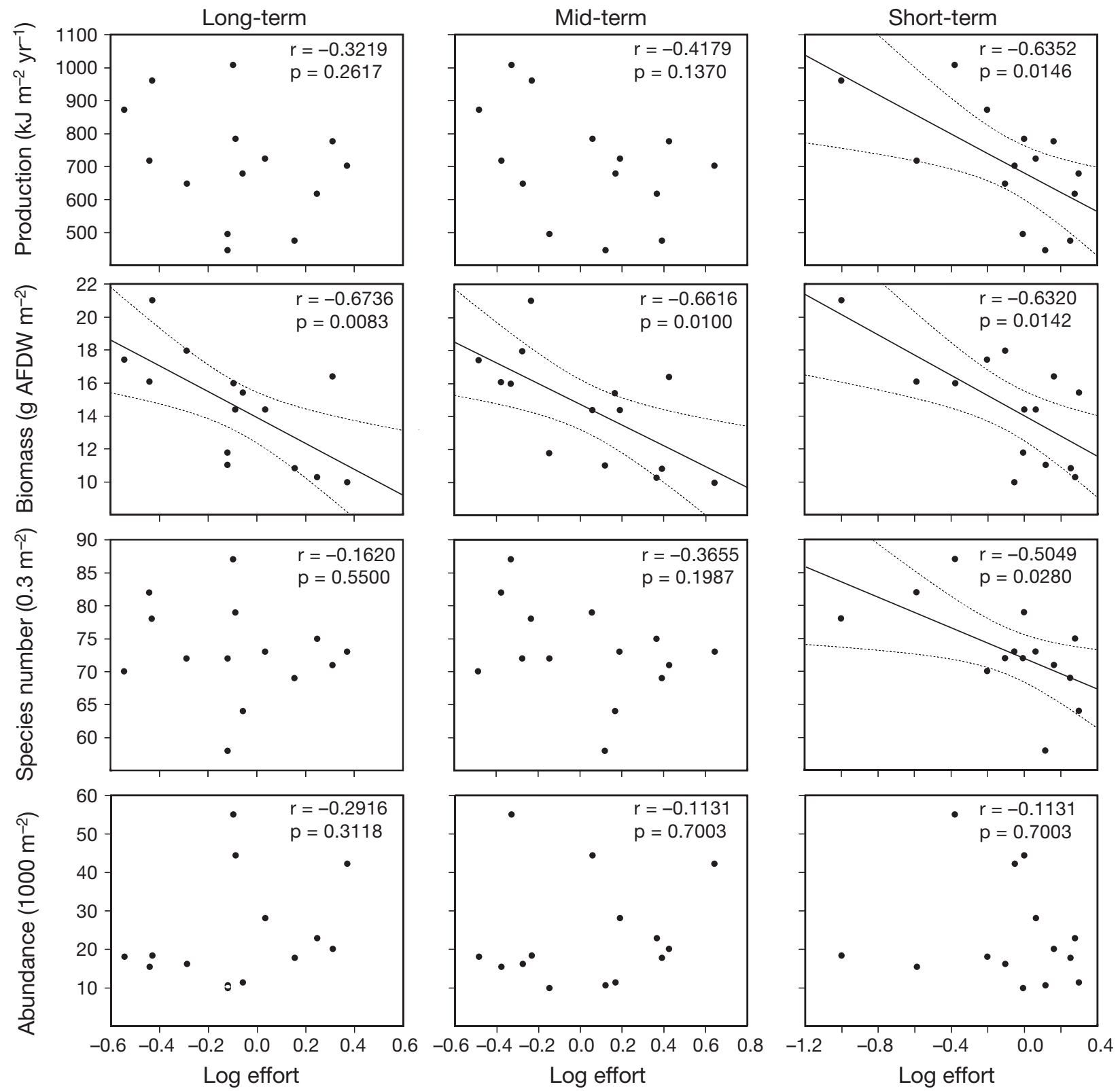

Fig. 2. Relationships between secondary production, biomass, species numbers, abundance and the different fishing effort regimes. Trend lines and $95 \%$ confidence limits are given for significant linear relationships

Table 3. Correlation coefficients (r) for the relationship between fishing effort and environmental variables. TOC: Total organic carbon, TON: total organic nitrogen. ${ }^{* *} \mathrm{p}<0.01$; ${ }^{*} \mathrm{p}<0.05$

\begin{tabular}{|lccc|}
\hline & $\begin{array}{c}\text { Long-term } \\
\text { effort }\end{array}$ & $\begin{array}{c}\text { Mid-term } \\
\text { effort }\end{array}$ & $\begin{array}{c}\text { Short-term } \\
\text { effort }\end{array}$ \\
\hline Mud & $-0.687^{* *}$ & $-0.609^{*}$ & -0.206 \\
TOC & $-0.754^{* *}$ & $-0.660^{*}$ & -0.172 \\
TON & $0.650^{*}$ & $-0.717^{* *}$ & -0.298 \\
C/N ratio & $0.866^{* *}$ & 0.504 & $0.623^{*}$ \\
Depth & 0.456 & 0.375 & 0.409 \\
Salinity & -0.366 & -0.299 & $-0.741^{* *}$ \\
Temperature & -0.132 & -0.050 & 0.232 \\
\hline
\end{tabular}

Mean total biomass showed similar relationships for the different size fractions $(4 \mathrm{~mm}$ : long-term $\mathrm{r}=$ $-0.660, \mathrm{p}=0.010$; mid-term $\mathrm{r}=-0.669$, $\mathrm{p}=0.009$; short-term $\mathrm{r}=-0.684, \mathrm{p}=0.007 ; 1 \mathrm{~mm}$ : not significant). No significant relationship was found between species number or total abundance and fishing effort except for an increase in the abundance of the $1 \mathrm{~mm}$ size fraction with increasing long-term fishing effort ( $\mathrm{r}=0.660, \mathrm{p}=0.010$ ).

Multivariate analysis using RDA and partitioning of variance for environmental and fishing effort variables revealed that the first 2 canonical axes could explain 

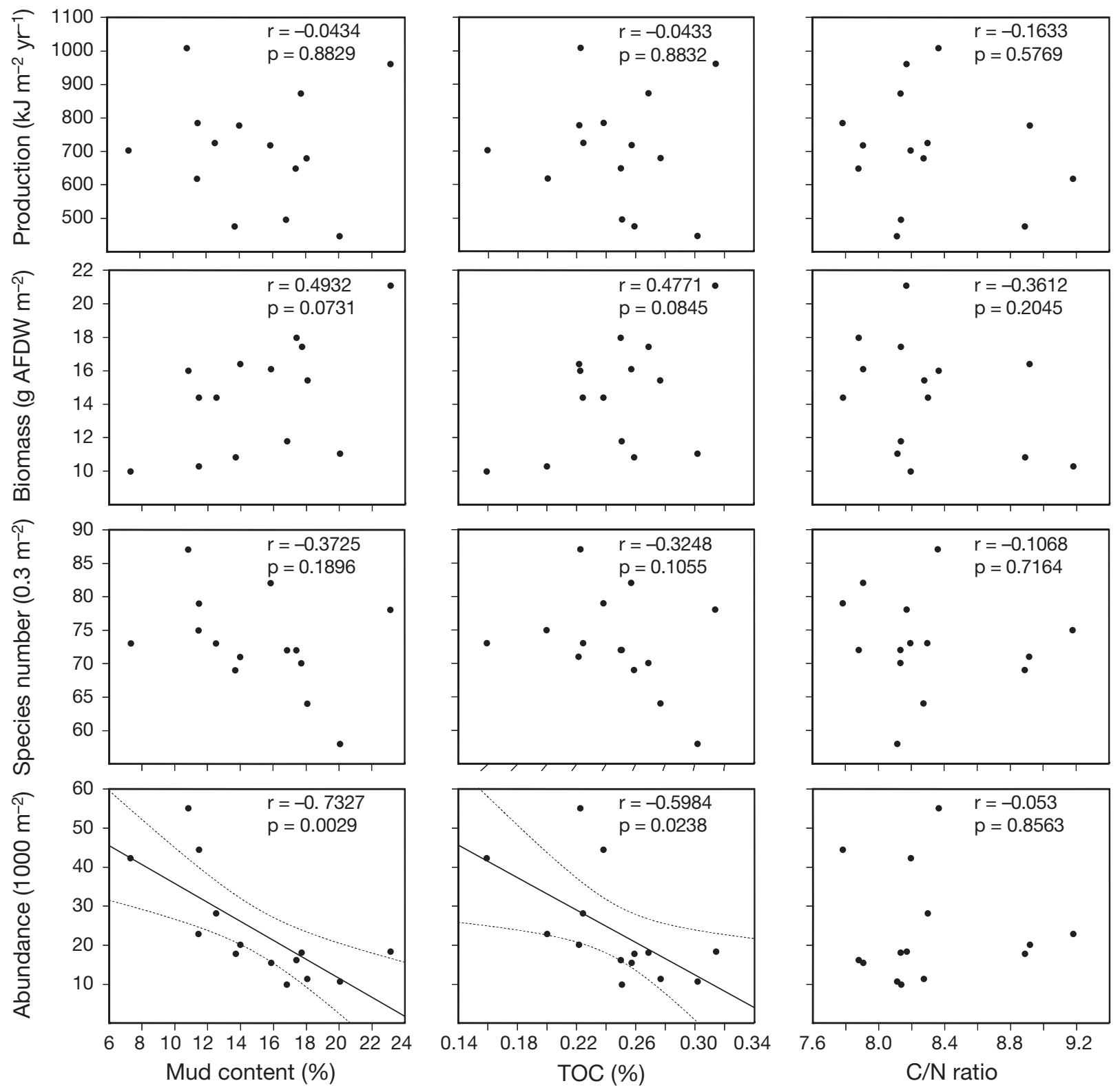

Fig. 3. Relationships between secondary production, biomass, species numbers, abundance and selected environmental variables (mud content, total organic carbon content and $\mathrm{C} / \mathrm{N}$ ratio). Trend lines and $95 \%$ confidence limits are given for significant linear relationships

53.7 and $50 \%$ of the variance in the square root-transformed abundance and biomass data, respectively. Fig. 5 shows the position of the stations relative to the first 2 axes, and indicates the relative importance of the environmental and fishing effort variables. Forward selection indicated that sediment variables were most important for structuring the infaunal community, both in terms of abundance and biomass. The effects of the variables mud content, TOC and TON were significant and explained much of the variance in the abundance data (marginal effects; Table 4). The same 3 environmental variables were the best predictors of variance in biomass data, although the effects were insignificant (Table 4). Stepwise inclusion of variables into the model revealed that mud content $(43 \%)$, short-term fishing effort (22\%) and salinity (8\%) had significant effects on abundance (conditional effects; Table 4). Mud content (17\%) and long-term fishing effort (23\%) were most important for the variance in the biomass data, but only the effect of the long-term fishing effort term was significant (Table 4).

Partial RDA and the variance partitioning method were used to separate the variance explained by the environmental variables, the fishing effort and the 
a

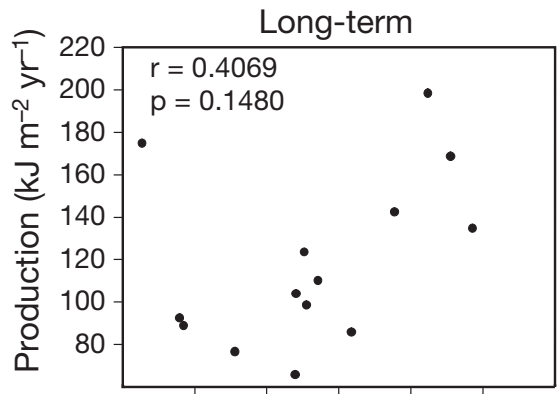

b

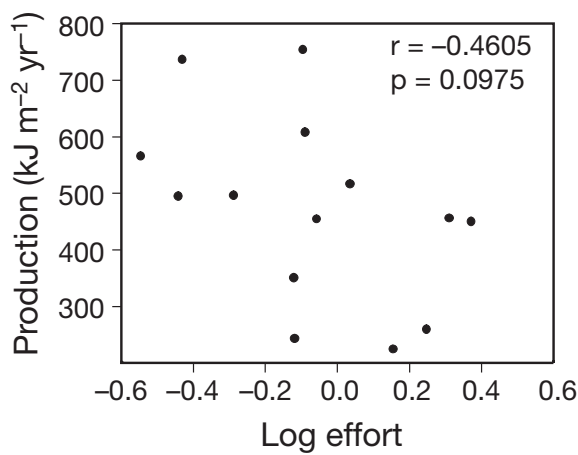

Mid-term
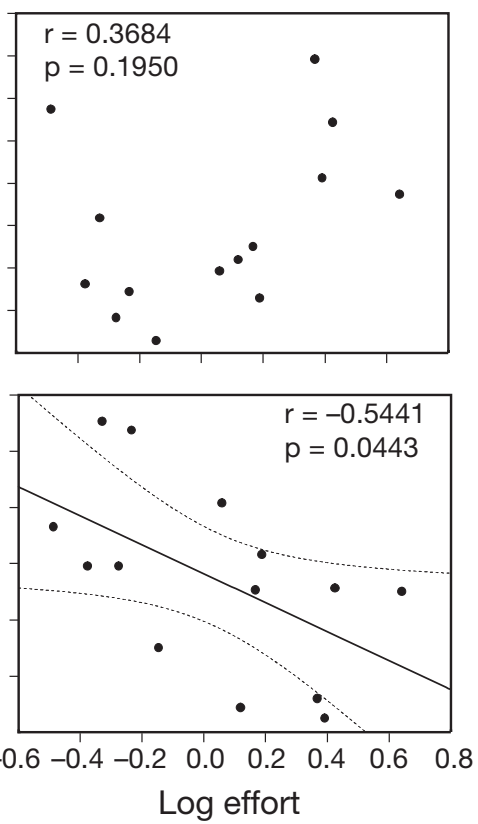

Short-term
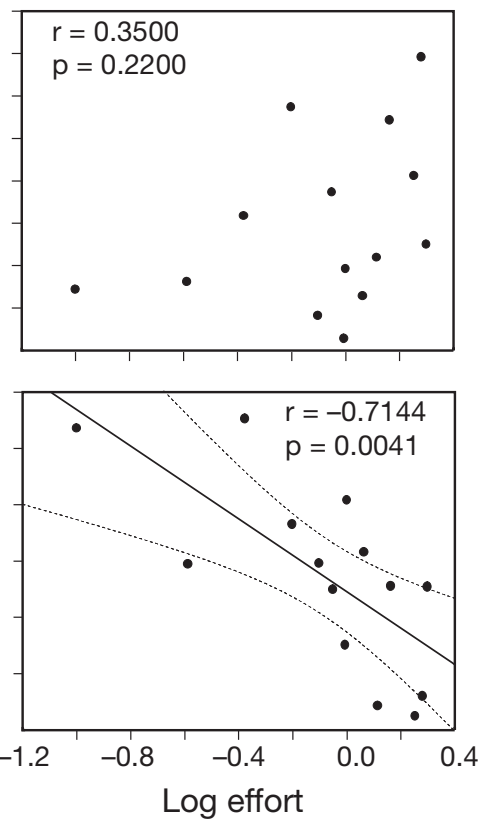

Fig. 4. Relationships between secondary production and the different fishing effort regimes for (a) the 1 mm size fraction, and (b) the $4 \mathrm{~mm}$ size fraction. Trend lines and $95 \%$ confidence limits are given for significant linear relationships

combined effects of all variables. The results for the square root-transformed abundance data showed that only $6.6 \%$ of the variance was explained by fishing effort, $33.5 \%$ by environmental variables and $13.9 \%$ by the combined effects of both (Fig. 6). In terms of biomass, the relative importance of fishing effort was somewhat higher, with $14.7 \%$ of the variance being explained by fishing effort, $33.5 \%$ by the environmental variables and only $1.8 \%$ by the combined effects of both. The low value of the shared effect on biomass indicates that fishing effort and environmental variables do not follow the same gradient.
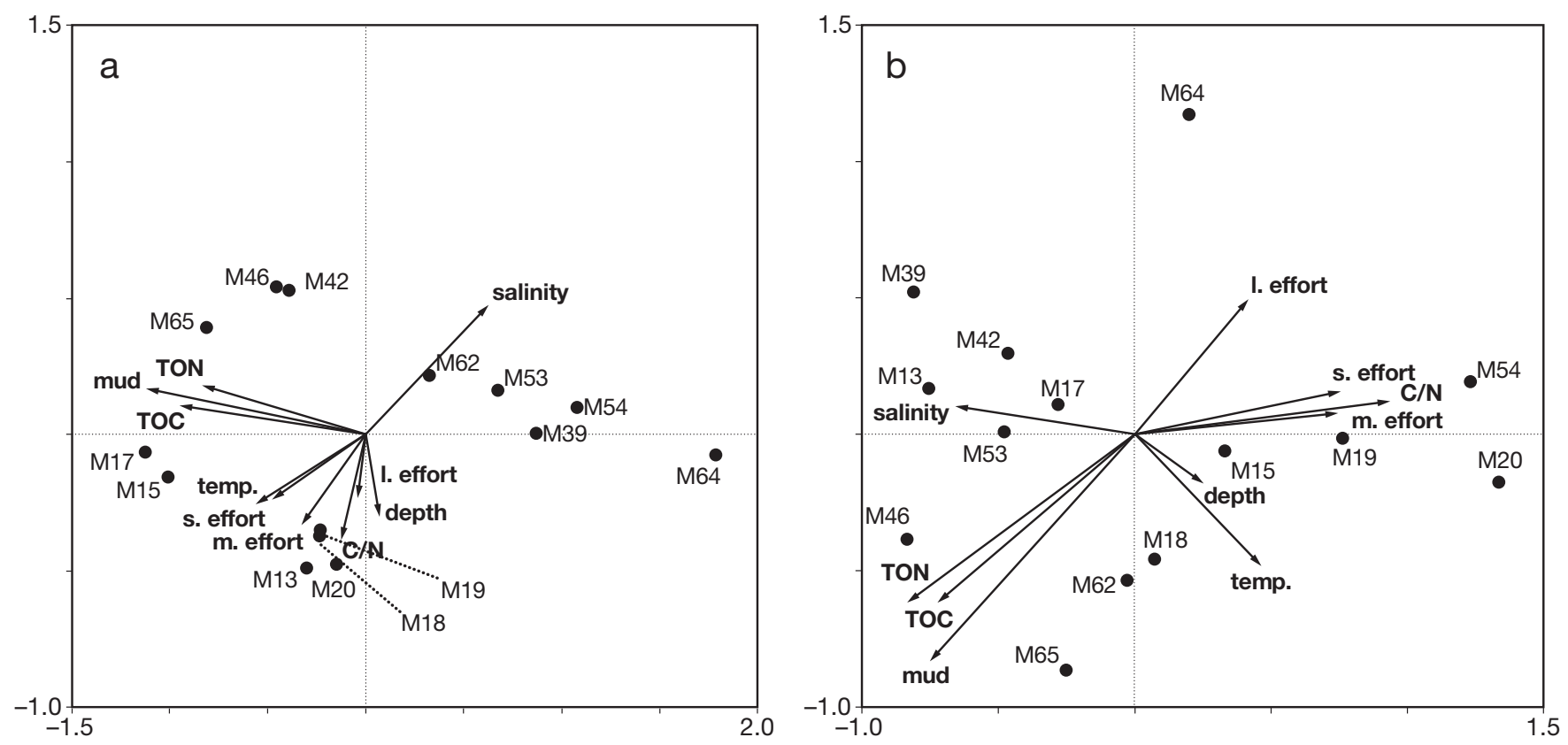

Fig. 5. Redundancy analysis (RDA) ordination diagrams based on (a) square root-transformed abundance data and (b) biomass data, with environmental variables and fishing effort (1./m./s.: long-/mid-/short-term, respectively) being shown as arrows 
Table 4. Redundancy analysis (RDA) for infauna, based on square-root transformed abundance data and biomass data. Marginal effects represent variance explained by each variable as the sole predictor variable $\left(\lambda_{1}\right)$. Conditional effects represent variance explained by each environmental variable, with the variables already selected being treated as covariables $\left(\lambda_{a}\right)$ based on forward selection. ${ }^{* *} \mathrm{p}<0.01 ;{ }^{*} \mathrm{p}<0.05$

\begin{tabular}{|c|c|c|c|c|c|}
\hline \multicolumn{6}{|c|}{ Square root-transformed abundance } \\
\hline & Axis 1 & Axis 2 & \multicolumn{3}{|l|}{ Axis 3} \\
\hline Eigenvalue & 0.657 & 0.112 & 0.033 & & \\
\hline $\begin{array}{l}\text { Species-environment } \\
\text { correlation }\end{array}$ & 0.932 & 0.989 & 0.995 & & \\
\hline \multicolumn{6}{|c|}{ Cumulative percentage variance } \\
\hline of species data & 65.7 & 76.9 & 80.2 & & \\
\hline \multirow[t]{3}{*}{ of species-env. relation } & 75.0 & 87.7 & 91.5 & & \\
\hline & \multicolumn{2}{|c|}{ Marginal effects } & & \multicolumn{2}{|c|}{ Conditional effects } \\
\hline & $\lambda_{1}$ & $\mathrm{p}$ & & $\lambda_{\mathrm{a}}$ & $\mathrm{p}$ \\
\hline Mud $(<63$ um) & 0.43 & $0.002^{* *}$ & & 0.43 & $0.002^{* *}$ \\
\hline TOC & 0.32 & $0.011^{*}$ & & 0.04 & 0.154 \\
\hline TON & 0.26 & $0.026^{*}$ & & 0.01 & 0.600 \\
\hline Salinity & 0.21 & 0.066 & & 0.08 & $0.040^{*}$ \\
\hline Short-term effort & 0.14 & 0.160 & & 0.22 & $0.004^{* *}$ \\
\hline Temperature & 0.11 & 0.242 & & 0.03 & 0.370 \\
\hline Mid-term effort & 0.09 & 0.333 & & 0.02 & 0.424 \\
\hline $\mathrm{C} / \mathrm{N}$ ratio & 0.07 & 0.414 & & 0.02 & 0.722 \\
\hline Long-term effort & 0.05 & 0.543 & & 0.01 & 0.840 \\
\hline Depth & 0.04 & 0.529 & & 0.02 & 0.502 \\
\hline \multicolumn{6}{|l|}{ Biomass } \\
\hline & Axis 1 & Axis 2 & Axis 3 & & \\
\hline Eigenvalue & 0.468 & 0.231 & 0.088 & & \\
\hline $\begin{array}{l}\text { Species-environment } \\
\text { correlation }\end{array}$ & 0.985 & 0.932 & 0.895 & & \\
\hline \multicolumn{6}{|c|}{ Cumulative percentage variance } \\
\hline of species data & 46.8 & 69.9 & 78.7 & & \\
\hline \multirow[t]{3}{*}{ of species-env. relation } & 53.7 & 80.2 & 90.3 & & \\
\hline & \multicolumn{2}{|c|}{ Marginal effects } & & \multicolumn{2}{|c|}{ Conditional effects } \\
\hline & $\lambda_{1}$ & $\mathrm{p}$ & & $\lambda_{\mathrm{a}}$ & $\mathrm{p}$ \\
\hline Mud (<63 um) & 0.17 & 0.063 & & 0.17 & 0.056 \\
\hline TON & 0.15 & 0.085 & & 0.05 & 0.336 \\
\hline TOC & 0.13 & 0.132 & & 0.08 & 0.176 \\
\hline $\mathrm{C} / \mathrm{N}$ ratio & 0.13 & 0.149 & & 0.10 & 0.272 \\
\hline Short-term effort & 0.11 & 0.199 & & 0.02 & 0.634 \\
\hline Mid-term effort & 0.11 & 0.212 & & 0.08 & 0.086 \\
\hline Salinity & 0.08 & 0.380 & & 0.05 & 0.244 \\
\hline Long-term effort & 0.08 & 0.375 & & 0.23 & $0.008^{* *}$ \\
\hline Temperature & 0.07 & 0.423 & & 0.02 & 0.768 \\
\hline Depth & 0.04 & 0.719 & & 0.07 & 0.242 \\
\hline
\end{tabular}

\section{DISCUSSION}

The southern North Sea has been heavily fished throughout the 20th century, with fishing pressure intensifying with the introduction of heavy beam trawling in the 1960s. This persistent disturbance to the benthic community from fishing may have altered the benthic fauna to form more resilient, disturbanceadapted communities (e.g. Kaiser et al. 2000a,b); this proposition is partly supported by the few available long-term comparisons of early century and more recent benthic faunal composition (Rumohr \& Kujawski 2000, Callaway et al. 2007). Our results here suggest that even in areas that have been heavily fished for decades, infaunal benthic invertebrate communities may remain sensitive to increases in fishing intensity. Thus, although a baseline shift in benthic communities due to chronic fishing disturbance has probably occurred in some areas of the North Sea during the last century, both infaunal community structure and parameters such as production, biomass and species number were still affected by disturbance due to trawling. This finding contrasts with the assertion that increased trawling effort in already heavily trawled areas would have little (if any) additional impact on benthic communities (e.g. Duplisea et al. 2002, Hiddink et al. 2006, Hilborn 2007), and may have important consequences for management.

To date, comparison of sites differing in fishing effort regime has often been hampered by similar gradients in environmental variables (e.g. Bergman \& van Santbrink 2000, Craeymeersch et al. 2000, Jennings et al. 2001a, Blyth et al. 2004, Queirós et al. 2006). On a large spatial scale, benthos abundance, distribution, and fishing effort have been found to follow the same environmental gradients (mainly depth and sediment composition), indicating that the distribution of benthos and, at least, the demersal fish species targeted by beam trawlers are influenced by the same environmental variables (Piet et al. 2000). Even on smaller spatial scales, fishing effort has been found to be closely related to sediment characteristics, making it difficult to distinguish between the effects of sediment structure and fishing disturbance (e.g. Queirós et al. 2006). In contrast, trawling can also change sediment characteristics and nutrient cycling due to disturbance and resuspension of the surface sediments (Mayer et al. 1991, Schwinghamer et al. 1998, Duplisea et al. 2001, Trimmer et al. 2005). Fishing disturbance was found to cause shifts in particle size towards the fine fraction (Trimmer et al. 2005) and vertical redistribution of fine particles and organic 


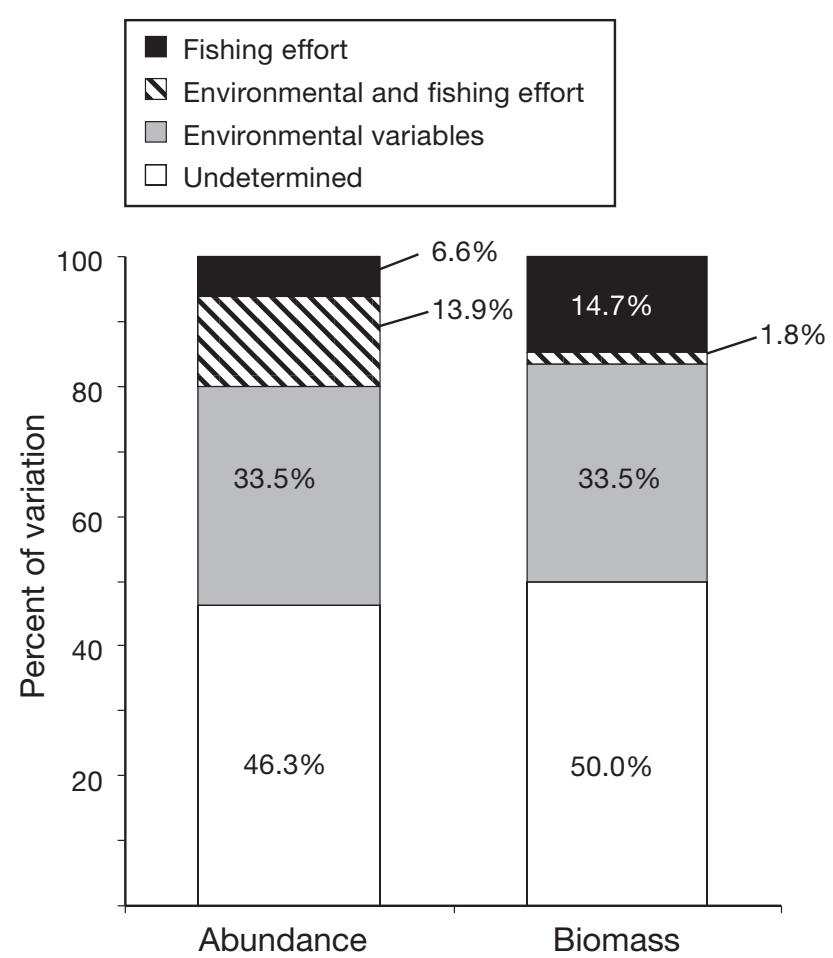

Fig. 6. Variation partitioning of the infauna community based on square root-transformed abundance and biomass data as revealed using RDA and partial RDA

matter (Mayer et al. 1991). Moreover, the release of $\mathrm{N}$ compounds following resuspension of the upper $2.4 \mathrm{~cm}$ of the sediment as modelled by Blackburn (1997) seems to be likely, since trawling gears usually penetrate the sediment beyond this depth (Fonteyne 1994). In our study, sediment variables such as mud and TOC content were also significantly correlated with longand mid-term fishing effort, suggesting that fishing patterns may follow the environmental strata or directly influence environmental (sediment) conditions, even at small spatial scales. However, the direct correlations between the faunal and environmental characteristics clearly showed that variation in environmental variables was not responsible for the observed declines in production, biomass and species richness of the infauna, leaving differences in fishing intensity to be the only possible factor to have significantly affected these infaunal community characteristics and processes. Other indirect effects of fishing on infauna might be an enhancement of benthic production due to increased primary production, which could result from the release of nutrients due to resuspension of sediments caused by fishing activities (Jennings et al. 2001a). However, these effects would take place on much larger spatial scales than addressed in this study. Furthermore, the locations where this effect may occur can be decoupled from the sites of actual fishing disturbance and may thus not be detected in this study.

Our finding that the infaunal community structure (in terms of abundance and to a lesser extent, of biomass) was determined by sediment variables such as mud content and TOC content rather than by fishing intensity seems to underpin the role of sediment characteristics in structuring infaunal communities. Sediment composition and, therewith, the quality and quantity of available organic matter, are known to structure benthic communities and determine the distribution of benthic infauna (e.g. Pearson \& Rosenberg 1987, Wieking \& Kröncke 2003, Kröncke et al. 2004, van Hoey et al. 2004). This seems to hold true even on a relatively small spatial scale in habitats with rather homogeneous sediment characteristics as in our study. Nevertheless, besides the observed decrease in total production, biomass and species numbers with increasing fishing effort, the results of the partial RDA show that after partitioning of the variance, the influence of the natural environmental variables was highest, with $33.5 \%$ of the variance in abundance and biomass being explained by the natural environmental variables. For biomass, $14.7 \%$ of the variance was still attributed to fishing effort, whereas only $6.6 \%$ of the variance in abundance was explained by fishing effort. Thus, sediment characteristics were most influential in determining the structure of the infaunal community and fishing had a slight impact on community structure in terms of biomass only.

Studies concerning fishing effects on benthic production have been mainly focused on the larger components of the benthos, such as epifauna and large infauna (e.g. Veale et al. 2000, Jennings et al. 2001b, Kenchington et al. 2001, Thrush et al. 2001, Hermsen et al. 2003). Here, we found a significant negative relationship between trawling and production of the whole infaunal community. However, in agreement with earlier studies, this effect was found to be driven mainly by the larger size fraction of the infauna sampled (Fig. 4). This can be explained by the fact that the fishing mortality rate of large sized infauna is typically found to be higher than for smaller organisms (e.g. Gilkinson et al. 1998). Although smaller animals tend to have higher individual rates of production, the calculation of total community production is strongly influenced by overall biomass; this would explain why there were significant effects of trawling intensity on overall production (Fig. 2), although patterns were contrasting in the small and large size classes (Fig. 4).

Trawling intensity had significant effects on total biomass, species richness and secondary production, but total biomass was the only variable for which a significant negative relationship was found over all the 
time scales of fishing disturbance examined. The different effort-aggregation categories (short-, mid- and long-term) were applied to obtain an indication of whether changes in infaunal communities were predominantly related to long-term or short-term disturbance patterns and processes. The effect on biomass over the long term is not surprising because the larger infauna, which characterize the biomass patterns, are mainly long-lived, slow growing species; thus, their recovery time after disturbance events might be longer than the disturbance frequency, resulting in a longterm change of biomass distribution. Total production, although strongly influenced by biomass, is also influenced by other factors such as temperature, which react over much shorter time scales. Large-bodied and fragile species are known to be strongly affected by fishing disturbance (e.g. De Groot \& Lindeboom 1994, Kaiser et al. 1998). In our study, mainly the brittle star Amphiura filiformis and the bivalves Nucula nitidosa and Chamelea gallina were found to have the lowest biomass and abundance values in the heavily trawled areas. This agrees with the results of Duineveld et al. (2007) who found higher abundance of bivalve and brittle star species in a closed area compared to the surrounding trawled areas in the southwestern North Sea. The decline of these species due to fishing disturbance may have further cascading effects on the diversity and functioning of the entire benthic community. Widdicombe et al. (2004) have shown that bioturbating echinoderm species such as Brissopsis lyrifers and Amphiura chiajei, which can be strongly affected by trawling activities, can significantly enhance infaunal diversity.

The most important target species for beam trawlers in the southern North Sea (the plaice and the sole), depend on infauna as their main food source (e.g. Rijnsdorp \& Vingerhoed 2001). Thus, changes in the production of infauna may also have important consequences for the targeted flatfish populations. It has been hypothesized that the establishment of the plaice box and the resulting reallocation of fishing effort may have decreased benthic production within the box, which may have led to changes in the spatial distribution of young plaice towards the more productive offshore areas in the 1990s (van Keeken et al. 2007). As mentioned above, the range of fishing effort applied in this study was not in the low-level effort range of the plaice box to address this hypothesis. Nevertheless, our results indicate that an increase in fishing effort in regularly fished areas would lead to a decrease in secondary production and biomass of infauna, and thus of food supply for the targeted flatfish species. Hiddink et al. (2008) suggested that the production of the infaunal component eaten by flatfish is higher in areas that are disturbed by trawling; thus, closing areas to trawling to protect flatfish species (i.e. the plaice box) can actually result in a reduction in food availability for the species that we are trying to protect (and subsequent migrations of the protected species out of the protected area). Here, we found that higher intensities of trawling were related to lower levels of production of the larger infauna that are likely to be predated by adult flatfish (4 mm sieve fraction), while there was no significant relationship of production with fishing intensity for the smallest size fraction (likely to be predated on by juvenile flatfish), although an increasing trend occurred. Especially for r-selected species, such as the tentaculate Phoronis muelleri and the polychaetes Owenia fusiformis and Lagis koreni, the highest abundances were found in the heavily trawled areas. These opportunistic species may indeed benefit from fishing disturbance due to their ability to respond to favourable conditions created by disturbance events by quickly using additional resources such as space and food (Pearson \& Rosenberg 1978, Warwick 1986). Nevertheless, the most affected and abundant species $P$. muelleri, is not at all used as a food source by benthivorous fish due to their chemical defence mechanisms against predators (Larson \& Stachowicz 2009, S. Schückel unpubl. data).

Thus, our results do not confirm the hypothesis that intensive trawling may directly lead to an increase in the production of food for commercial species such as flatfish; however, the range of trawling intensity covered in our study did not extend to levels as low as those recorded in closed areas.

Our results show that bottom trawling also affects the infaunal components of the benthic ecosystem and, therewith, the lower levels of the food web. This in turn has ramifications for fisheries management especially in the context of an ecosystem approach, which has to incorporate all ecosystem components affected by fishing activities. Our results also demonstrate that in a heavily trawled area such as the German Bight, the spatial distribution of fishing effort is still patchily distributed even within small areas with similar habitat characteristics. It has been suggested that fisheries management strategies that preserve patchy but temporally stable fishing distribution would have lower total impact on the benthic fauna than strategies that lead to a homogenisation of fishing effort (e.g. Jennings et al. 2002, Queirós et al. 2006). Of course, this depends mainly on the specific ecosystem management objectives. Although it is yet unclear which nontarget ecosystem properties and components need to be managed within an ecosystem approach, our results indicate that regulation of fishing effort will influence infaunal production, biomass, species number and to a lesser extent, community structure, even in areas with high chronic fishing disturbance. 
Acknowledgements. This work was supported by the European Commission project 'Managing Fisheries to Conserve Groundfish and Benthic Invertebrate Species Diversity' (MAFCONS EC project Q5RS-2002-00856). The work of H.R. was additionally supported by the NWO-Prioriteit Programma 'Sustainable Use and Conservation of Marine Living Resources', Project No. 885-10-317. We thank the anonymous referees for their valuable comments.

\section{LITERATURE CITED}

Bergman MJN, van Santbrink JW (2000) Fishing mortality of populations of megafauna in sandy sediments. In: Kaiser MJ, De Groot SJ (eds) Effects of fishing on non-target species and habitats: biological, conservation and socioeconomic issues. Blackwell Science, Oxford, p 49-69

Blackburn TH (1997) Release of nitrogen compounds following resuspension of sediment: model predictions. J Mar Syst 11:343-352

Blyth RE, Kaiser MJ, Edwards-Jones G, Hart PJB (2004) Implications of a zoned fishery management system for marine benthic communities. J Appl Ecol 41:951-961

Borcard D, Legendre P, Drapeau P (1992) Partialling out the spatial component of ecological variation. Ecology 73: 1045-1055

Brey T (2001) Population dynamics in benthic invertebrates. A virtual handbook. Version 01.2. www.thomas-brey.de/ science/virtualhandbook/ (accessed April 2008)

Callaway R, Engelhard GH, Dann J, Cotter J, Rumohr H (2007) A century of North Sea epibenthos and trawling: comparison between 1902-1912, 1982-1985 and 2000. Mar Ecol Prog Ser 346:27-43

Clarke KR, Warwick RM (1994) Change in marine communities: an approach to statistical analysis and interpretation. Plymouth Marine Laboratory

Collie JS, Hall SJ, Kaiser MJ, Poiner IR (2000) A quantitative analysis of fishing impacts on shelf-sea benthos. J Anim Ecol 69:785-798

Craeymeersch JA, Piet GJ, Rijnsdorp AD, Buijs J (2000) Distribution of macrofauna in relation to the micro-distribution of trawling effort. In: Kaiser MJ, de Groot SJ (eds) Effects of fishing on non-target species and habitats: biological, conservation and socio-economic issues. Blackwell Science, Oxford, p 187-197

Cury PA, Christensen V (2005) Quantitative ecosystem indicators for fisheries management. ICES J Mar Sci 62:307-310

> Daan N, Bromley PJ, Hislop JRG, Nielsen NA (1990) Ecology of North Sea fish. Neth J Sea Res 26:343-386

De Groot SJ, Lindeboom H (1994) Environmental impact of bottom gears on benthic fauna in relation to natural resources management and protection of the North Sea. NIOZ-Rapport 1994-11. Netherlands Institute for Fisheries Research, Texel

Duineveld GCA, Bergman MJN, Lavaleye MSS (2007) Effects of an area closed to fisheries on the composition of the benthic fauna in the southern North Sea. ICES J Mar Sci 64:899-908

Duplisea DE, Jennings S, Malcolm SJ, Parker R, Sivyer DB (2001) Modelling potential impacts of bottom trawl fisheries on soft sediment biogeochemistry in the North Sea. Geochem Trans 14:1-6

- Duplisea DE, Jennings S, Warr KJ, Dinmore TA (2002) A sizebased model of the impacts of bottom trawling on benthic community structure. Can J Fish Aquat Sci 59:1785-1795

Ehrich S, Adlerstein S, Brockmann U, Floeter J and others (2007) 20 years of the German small-scale bottom trawl survey (GSBTS): a review. Senckenb Marit 37:13-82
Fonteyne R (1994) Physical impact of a 4-m beam trawl. In: de Groot SJ, Lindeboom HJ (eds) Environmental impact of bottom gears on benthic fauna in relation to natural resources management and protection of the North Sea. NIOZ-Rapport 1994-11, Rivo-DLO report C026/94, p 21-58

Frid CLJ, Clark RA, Hall JA (1999) Long-term changes in the benthos on a heavily fished ground off the NE coast of England. Mar Ecol Prog Ser 188:13-20

Frid CLJ, Paramor OAL, Scott CL (2006) Ecosystem-based management of fisheries: is science limiting? ICES J Mar Sci 63:1567-1572

Garcia SM, Cochrane KL (2005) Ecosystem approach to fisheries: a review of implementation guidelines. ICES J Mar Sci 62:311-318

Gilkinson K, Paulin M, Hurley S, Schwinghamer P (1998) Impacts of trawl door scouring on infaunal bivalves: results of a physical trawl door model/dense sand interaction. J Exp Mar Biol Ecol 224:291-312

Gislason H, Sinclair M, Sainsbury K, O'Boyle R (2000) Symposium overview: incorporating ecosystem objectives within fisheries management. ICES J Mar Sci 57:468-475

Greenstreet SPR, Piet GJ (2008) Assessing the sampling effort required to estimate $\alpha$ species diversity in the groundfish assemblages of the North Sea. Mar Ecol Prog Ser 364: 181-197

Greenstreet SPR, Spence FB, Shanks AM, McMillan JA (1999) Fishing effects in northeast Atlantic shelf seas: patterns in fishing effort, diversity and community structure. II. Trends in fishing effort in the North Sea by UK registered vessels landing in Scotland. Fish Res 40:107-124

Hall SJ, Mainprize B (2004) Towards ecosystem-based fisheries management. Fish Fish 5:1-20

Hedges JI, Stern JH (1984) Carbon and nitrogen determinations of carbonate-containing solids. Limnol Oceanogr 29: $657-663$

> Hermsen JM, Collie JS, Valentine PC (2003) Mobile fishing gear reduces benthic megafaunal production on Georges Bank. Mar Ecol Prog Ser 260:97-108

Hiddink JG, Jennings S, Kaiser MJ, Queirós AM, Duplisea DE, Piet GJ (2006) Cumulative impacts of seabed trawl disturbance on benthic biomass, production, and species richness in different habitats. Can J Fish Aquat Sci 63:721-736

Hiddink JG, Rijnsdorp AD, Piet G (2008) Can bottom trawling disturbance increase food production for a commercial fish species? Can J Fish Aquat Sci 65:1393-1401

> Hilborn R (2007) Reinterpreting the state of fisheries and their management. Ecosystems 10:1362-1369

> Jennings S, Alsvag J, Cotter AJ, Ehrich S and others (1999) Fishing effects in northeast Atlantic shelf seas: patterns in fishing effort, diversity and community structure. III. International trawling effort in the North Sea: an analysis of spatial and temporal trends. Fish Res 40:125-134

Jennings S, Dinmore TA, Duplisea DE, Warr KJ, Lancaster JE (2001a) Trawling disturbance can modify benthic production processes. J Anim Ecol 70:459-475

Jennings S, Pinnegar JK, Polunin NVC, Warr KJ (2001b) Impacts of trawling disturbance on the trophic structure of benthic invertebrate communities. Mar Ecol Prog Ser 213: $127-142$

Jennings S, Nicholson MD, Dinmore TA, Lancaster JE (2002) Effects of chronic trawling disturbance on the production of infaunal communities. Mar Ecol Prog Ser 243:251-260

Jongman RHG, ter Braak CJF, van Tongeren OFR (1995) Data analysis in community and landscape ecology. Cambridge University Press, Cambridge

Kaiser MJ, Spencer BE (1996) The effects of beam-trawl disturbance on infaunal communities in different habitats. 
J Anim Ecol 65:348-358

Kaiser MJ, Edwards DB, Armstrong PJ, Radford K, Lough NEL, Flatt RP, Jones HD (1998) Changes in megafaunal benthic communities in different habitats after trawling disturbance. ICES J Mar Sci 55:353-361

Kaiser MJ, Ramsay CA, Richardson CA, Spence FE, Brand AR (2000a) Chronic fishing disturbance has changed shelf sea benthic community structure. J Anim Ecol 69:494-503

Kaiser MJ, Spence FE, Hart PJB (2000b) Fishing-gear restrictions and conservation of benthic habitat complexity. Conserv Biol 14:1512-1525

Kaiser MJ, Clarke KR, Hinz H, Austen MCV, Somerfield PJ, Karakassis I (2006) Global analysis of response and recovery of benthic biota to fishing. Mar Ecol Prog Ser 311:1-14

Kenchington ELR, Prena J, Gilkinson KD, Gordon DC and others (2001) Effects of experimental otter trawling on the macrofauna of a sandy bottom ecosystem on the Grand Banks of Newfoundland. Can J Fish Aquat Sci 58: 1043-1057

> Kenchington ELR, Gilkinson KD, MacIssaac KG, Bourbonnais-Boyce C, Kenchington TJ, Smith SJ, Gordon DC (2006) Effects of experimental otter trawling on benthic assemblages on Western Bank, northwest Atlantic Ocean. J Sea Res 56:249-270

Kröncke I, Rachor E (1992) Macrofauna investigations along a transect from the inner German Bight towards the Dogger Bank. Mar Ecol Prog Ser 91:269-276

Kröncke I, Stoeck T, Wieking G, Palojärvi A (2004) Relationship between structural and trophic aspects of microbial and macrofaunal communities in different areas of the North Sea. Mar Ecol Prog Ser 282:13-31

Larson AA, Stachowicz JJ (2009) Chemical defense of a softsediment dwelling phoronid against local epibenthic predators. Mar Ecol Prog Ser 374:101-111

- Mayer LM, Schick DF, Findlay RH, Rice DL (1991) Effects of commercial dragging on sedimentary organic matter. Mar Environ Res 31:249-261

Pastoors MA, Rijnsdorp AD, van Beek FA (2000) Effects of a partially closed area in the North Sea ('plaice box') on stock development of plaice. ICES J Mar Sci 57:1014-1022

Pearson TH, Rosenberg R (1978) Macrobenthic succession in relation to organic enrichment and pollution of the marine environment. Oceanogr Mar Biol Annu Rev 16:229-311

Pearson TH, Rosenberg R (1987) Feast and famine: structuring factors in marine benthic communities. In: Gee JHR, Giller PS (eds) The 27th Symposium of the British Ecological Society, Aberystwyth, 1986. Blackwell Scientific Publications, Oxford, p 373-395

Piet GJ, Rijnsdorp AD (1998) Changes in the demersal fish assemblage in the south-eastern North Sea following the establishment of a protected area ('plaice box'). ICES J Mar Sci 55:420-429

Piet GJ, Rijnsdorp AD, Bergman MJN, van Santbrink JW, Craeymeersch J, Buijs J (2000) A quantitative evaluation of the impact of beam trawling on benthic fauna in the southern North Sea. ICES J Mar Sci 57:1332-1339

Piet GJ, Quirijns FJ, Robinson L, Greenstreet SPR (2007) Potential pressure indicators for fishing, and their data requirements. ICES J Mar Sci 64:110-121

> Queirós AM, Hiddink JG, Kaiser MJ, Hinz H (2006) Effects of chronic bottom trawling disturbance on benthic biomass, production and size spectra in different habitats. J Exp Mar Biol Ecol 335:91-103

Reiss H, Kröncke I (2005) Seasonal variability of infaunal community structures in three areas of the North Sea under different environmental conditions. Estuar Coast Shelf Sci 65:253-274

Ricciardi A, Bourget E (1998) Weight-to-weight conversion

Editorial responsibility: Mike Elliott,

Hull, UK factors for marine benthic macroinvertebrates. Mar Ecol Prog Ser 163:245-251

Rijnsdorp AD, Vingerhoed B (2001) Feeding of plaice Pleuronectes platessa L. and sole Solea solea (L.) in relation to the effects of bottom trawling. J Sea Res 45:219-229

Rumohr H, Kujawski T (2000) The impact of trawl fishery on the epifauna of the southern North Sea. ICES J Mar Sci 57: 1389-1394

Rumohr H, Brey T, Ankar S (1987) A compilation of biometric conversion factors for benthic invertebrates of the Baltic Sea. Balt Mar Biol Publ 9:1-56

Sanchez P, Demestre M, Ramon M, Kaiser MJ (2000) The impact of otter trawling on mud communities in the northwestern Mediterranean. ICES J Mar Sci 57:1352-1358

Schwinghamer P, Gordon DC, Rowell TW, Prena J, McKeown DL, Sonnichsen G, Guigne JY (1998) Effects of experimental otter trawling on surficial sediment properties of a sandy-bottom ecosystem on the Grand Banks of Newfoundland. Conserv Biol 12:1215-1222

ter Braak CJF, Smilauer P (1998) CANOCO reference manual and user's guide to Canoco for windows: software for canonical community ordination (version 4). Microcomputer Power, Ithaca, NY

$>$ ter Braak CJF, Verdonschot PFM (1995) Canonical correspondence analysis and related multivariate methods in aquatic ecology. Aquat Sci 57:255-289

Thrush SF, Hewitt JE, Cummings VJ, Dayton PK (1995) The impact of habitat disturbance by scallop dredging on marine benthic communities: What can be predicted from the results of experiments? Mar Ecol Prog Ser 129:141-150

Thrush SF, Hewitt JE, Funnell GA, Cummings VJ and others (2001) Fishing disturbance and marine biodiversity: the role of habitat structure in simple soft-sediment systems. Mar Ecol Prog Ser 223:277-286

Tillin HM, Hiddink JG, Jennings J, Kaiser MJ (2006) Chronic bottom trawling alters the functional composition of benthic invertebrate communities on a sea-basin scale. Mar Ecol Prog Ser 318:31-45

Trimmer M, Petersen J, Sivyer DB, Mills C, Young E, Parker ER (2005) Impact of long-term benthic trawl disturbance on sediment sorting and biogeochemistry in the southern North Sea. Mar Ecol Prog Ser 298:79-94

> Tuck ID, Hall SJ, Robertson MR, Armstrong E, Basford DJ (1998) Effects of physical trawling disturbance in a previously unfished sheltered Scottish sea loch. Mar Ecol Prog Ser 162:227-242

van Hoey G, Degrear S, Vincx M (2004) Macrobenthic community structure of soft-bottom sediments at the Belgian Continental Shelf. Estuar Coast Shelf Sci 59:599-613

van Keeken OA, van Hoppe M, Grift RE, Rijnsdorp AD (2007) Changes in the spatial distribution of North Sea plaice (Pleuronectes platessa) and implications for fisheries management. J Sea Res 57:187-197

Veale LO, Hill AS, Hawkins SJ, Brand AR (2000) Effects of long-term physical disturbance by commercial scallop fishing on subtidal epifaunal assemblages and habitats. Mar Biol 137:325-337

Warwick RM (1986) A new method for detecting pollution effects on marine macrobenthic communities. Mar Biol 92: $557-562$

Widdicombe S, Austen MC, Kendall MA, Olsgard F, Schaaning MT, Dashfield SL, Needham HR (2004) Importance of bioturbators for biodiversity maintenance: indirect effects of fishing disturbance. Mar Ecol Prog Ser 275:1-10

Wieking G, Kröncke I (2003) Macrofauna communities of the Dogger Bank (central North Sea) in the late 1990s: spatial distribution, species composition and trophic structure. Helgol Mar Res 57:34-46

Submitted: October 1, 2008; Accepted: July 27, 2009

Proofs received from author(s): October 29, 2009 